\section{Threats faced by brown rot of potato in Bangladesh}

\author{
Rajesh Chakraborty, Tuhin Suvra Roy \\ Department of Agronomy, Sher-e-Bangla \\ Agricultural University, Dhaka, \\ Bangladesh
}

\begin{abstract}
Potato is the most important root crop in Bangladesh. The field production is very much lower compared to other developed countries. Pests and diseases hampered the production due to the prevailing climatic condition, which favors the development in Bangladesh of specific diseases. Among them Brown rot (Ralstonia solanacearum) is the most alarming disease at present and previous time. The major areas of Bangladesh have faced many hampers on this disease. The potato growers and businessmen of Bangladesh are facing much problems on this disease especially in case of export to other countries as Russia, Malaysia, Singapore, Indonesia, Sri Lanka, Thailand, Hong Kong, Vietnam, Maldives, Turkey, Azerbaijan, Ethiopia and Nigeria. But during last year Russian Government banned import potatoes from Bangladesh. So, from these perspectives, this concept paper was studied to evaluate the most appropriate status of this disease caused by organisms and its best control strategies to impart better production thinking for Bangladeshi potato growers, exporters and other related personnels.
\end{abstract}

\section{Introduction}

Potato (Solanum tuberosum) is the $4^{\text {th }}$ world crop after wheat, rice and maize. Bangladesh is the $7^{\text {th }}$ potato producer Country in the world. ${ }^{1}$ In Bangladesh, it ranks $2^{\text {nd }}$ after rice in production. The total area under potato crop, national average yield and total production in Bangladesh are 430,446 hectares, 19,071 tons ha $^{-1}$ and 8,205,470 metric tons, respectively. Total production is increasing day by day as such consumption also rapidly increasing in Bangladesh. $^{2} R$. solanacearum constitutes a serious obstacle to the culture of many solanaceous plants in both tropical and temperate regions. It also causes vascular wilt symptoms on many plants especially tomato, eggplant, potato etc., but potato faces much more problems caused by this organism in Bangladesh, then in the rest of the world. The greatest economic damage has been reported on potatoes, tobacco and tomatoes in the southeastern
USA, Indonesia, Brazil, Colombia and South Africa. In the Philippines, in 1966-1968, there were average losses of $15 \%$ in tomatoes, $10 \%$ in aubergines and Capsicum, and 2-5\% in tobacco. ${ }^{3}$ In the Amazon basin in Peru, about half of the banana plantations are affected and the pathogen threatens which destroy plantations throughout the Peruvian jungle rapidly spread. ${ }^{4}$ In India, there are sometimes total losses in tomato crops. In the eradicated outbreak in Israel, losses occurred in potato, being heavier for the spring crop than the autumn crop, because of the high temperatures under which the former matures. ${ }^{5}$ Extensive losses on potato were reported in Greece in 1951-1953. ${ }^{6}$ Disease severity mostly increases if $R$. solanacearum is found in association with root nematodes. In tobacco, nematode infestation changes the physiology of the plants, causing susceptibility to bacterial wilt. ${ }^{7}$ Experiments in India showed that the combined pathogenic effects of $R$. solanacearum and Meloidogyne javanica were greater than the independent effects of either. ${ }^{8}$ Bangladeshi businessmen usually export potato to Russia, Malaysia, Singapore, Indonesia, Sri Lanka, Thailand, Hong Kong, Vietnam, Maldives, Turkey, Azerbaijan, Ethiopia and Nigeria. But the Russian Federation has imposed a temporary ban on import of potatoes from Bangladesh. The principle objectives under the present study is to highlight the major affected areas of Bangladesh from brown rot and to evaluate the most appropriate status of this disease causing organism and its better control strategies to impart a better production thinking for Bangladeshi potato growers, exporters and others related personnel's.

\section{Discussion}

\section{Production and export threats}

The production of potato in Bangladesh is more or less steady from the ancient times regarding the quality. At the door of bright quality, potato production in Bangladesh, there is an enemy, brown rot, interrupted the growth rates of potato and the production was affected by brown rot organisms at previous time (Table 1), which leads to estimated losses for farmers. In Bangladesh the Northwest, Central, Southern and Northeast areas were mostly hampered from brown rot of potatoes with the estimated losses were 16.0, 20.0, 5.5 and $15.0 \%$, respectively, those were also presented in Table 1. The Cardinal, Patrones and Diamant were the most important varieties. ${ }^{9}$

During the fiscal year (2014-2015), exports of the produced potato had made so much hinders because, about 104 tons of ware potatoes that arrived in the seaport of Vladivostok (Russia) from the People's Republic of
Correspondence: Rajesh Chakraborty, Department of Agronomy, Sher-e-Bangla Agricultural University, Dhaka-1207,

Bangladesh.

Tel.: +88.01741664970, Fax: +88.0258155800 .

E-mail: rajeshmadhobi9@gmail.com

Key words: Brown rot of potato; Export; Status; Control.

Acknowledgements: the authors are very much thankful to Ministry of Education, The People's Republic of Bangladesh to provide partial financial support for this study. This part may not be applicable for our present study. Some overview of bacterial ooze was studied by the order of Department of Plant Pathology, Sher-e-Bangla Agricultural University, Dhaka-1207, Bangladesh, without any identifier number.

Contributions: RC, wrote this manuscript by collecting the secondary sources of information; TSR, helped to revise the manuscript to give the present format.

Conflict of interest: the authors declare no potential conflict of interest.

Funding: the piece of work was partially funded by the Ministry of Education, but the rest transport cost was bearded by authors for collecting information.

Dedication: Authors would like to dedicate the piece of work to the people of Bangladesh who much suffering for the Brown rot of potato.

Received for publication: 29 December 2015 . Revision received: 1 February 2016

Accepted for publication: 1 February 2016.

This work is licensed under a Creative Commons Attribution NonCommercial 4.0 License (CC BYNC 4.0).

(c)Copyright R.Chakraborty and T.S. Roy, 2016

Licensee PAGEPress, Italy

Microbiology Research 2016; 7:6258

doi:10.4081/mr.2016.6258

Bangladesh in May, 2014 appeared that infected with a dangerous quarantine disease-potato brown rot (Ralstonia solanacearum). So as a result, the import of unsafe agricultural products has been banned. Rosselkhoznadzor (Federal Service for Veterinary and Phytosanitary Surveillance) in PrimorskyKrai and Sakhalin Region prescribed to return the infected consignment of potatoes back to the country-exporter. The serious bacterial disease of potato imported into PrimorskyKrai has been detected for the fourth time (Source: Fresh Plaza). However, batches of potatoes that had been shipped earlier might be permitted to enter the Russian market only if it passed 
through laboratory tests, according to the Foreign Affairs and Agriculture Ministries. The Russian Federation apprised the Agriculture Ministry several times that they want to see that Bangladesh growing bacteria-free potatoes to comply with the standard set by the Russian government for ensuring market access to Russian Federation. The Russian delegation from where they got such a bad impression. Earlier some bacteria were found in potatoes exported to Russia. Bangladeshi businessmen usually export potato to Russia, Malaysia, Singapore, Indonesia, Sri Lanka, Thailand, Hong Kong, Vietnam, the Maldives, Turkey, Azerbaijan, Ethiopia and Nigeria. The seed wing of the Department of Agricultural Extension has selected cultivable land for production of potatoes in some selected districts under the supervision of the committee. The selected areas include Rajbari, Dhaka, Tangail, Meherpur, Lalmonirhat, Nilphamari, Kurigram, Sherpur, Kishoreganj and Munshiganj.

Bangladesh annually exports around 1-lakh tons of potatoes to different countries including Russia (Source: Dhaka Tribune). So, on the basis of present reveals, it maybe said that Bangladesh has many opportunities on potato exports but such type of organisms failed this aim. In the meantime, we have taken enough measures and we have searched the overcoming of this problem.

\section{Brief history of causal organisms (sub-tropical)}

Brown rot or bacterial wilt is a destructive disease of the potato. This disease is also known as root rot. ${ }^{10}$ The organism creates this disease known as Ralstonia solanacearum. Other common names are: Bacterium solanacearum (Smith) Chester, Burkholderia solanacearum (Smith) Yabuuchi, Pseudomonas solanacearum (Smith) Smith.

The occurrence of different races and strains of the pathogen with varying virulence under different environmental conditions presents a serious danger for Bangladesh, due to changes of natural climatic condition. Absence of the bacterium is an important consideration for countries exporting seed potatoes. Hosts other than potato are most likely to be affected in the warmer parts of the Bangladesh, where the bacterium already occurs. However, even in these areas, races other than race 3 have not been positively identified and the introduction of someone from many strains not occurring in the region could have a great economic impact. Race 3 (biovar 2) appears to be presented as the most important risk for the potato-growing region of Bangladesh as a whole. These are a definite risk that it spread through imports of (latently) infected early ware potatoes or seed potatoes from countries where the disease now occurs. Furthermore, introduction of $R$. solanacearum by use of (latently) infected potatoes as cattle fodder or for industrial processing is a potential risk if the potatoes, or wastes derived from them, are reintroduced into the agricultural system.

$R$. solanacearum is a Gram-negative rod, 0.5-1.5 $\mu \mathrm{m}$ in length, with a single polar flagellum. The positive staining reaction for poly- $ß$ hydroxybutyrate granules with Sudan Black B or Nile blue distinguishes $R$. solanacearum from Erwinia species.

In addition, $R$. solanacearum stains heavily at the poles with carbolfuchsin. Agar colonies are initially smooth, shining and opalescent, but become brown with age. ${ }^{11} R$. solanacearum does not behave as a single bacterium with a uniform biology and host range, but as a complex of variants, variously described as groups, races, biovars, biotypes, sub-races and strains. The different classifications of $R$. solanacearum have caused a considerable amount of confusion in literature, ${ }^{12}$ distinguishing three races on the basis of pathogenicity viz., Race 1, Race 2 and Race 3 . Since Bangladesh is situated in sub-tropical area, the Race 3 is the most important for brown rot disease on potato. Because Bangladesh belongs to the warm and moist soil condition, which favors this pathogen to develop.

Race 3: Affecting mainly potatoes without a high virulence on other solanaceous crops, with lower temperature optimum $\left(27^{\circ} \mathrm{C}\right)$. Other hosts are the weeds $S$. dulcamara, $S$. nigrum, $S$. cinereum. Only race 3 , the potato race, is equivalent to Biotype II. ${ }^{13}$ Race 3 (biovar 2) appeared in many fingerprinting studies to be very homogeneous. South America is the possible origin of race 3 . The disease is most severe at $24-35^{\circ} \mathrm{C}$; it is seldom found in temperate climates where the mean temperature for any winter month falls below $10^{\circ} \mathrm{C}$. There are distinct temperature requirements for optimum disease development and reproduction for the different races (biovars). High soil moisture and periods of wet weather or rainy seasons are associated with high disease severity.

Soil moisture is also one of the major factors affecting reproduction and survival of the pathogen; the most favorable soil moisture is 0.5 to -1 bar while -5 to -15 bars are unfavor-

Table 1. Scenarios of brown rot disease in Bangladesh (1993).

\begin{tabular}{lcc} 
Areas & Potato cultivars & Estimated losses (\%) \\
Northwest & Cardinal & 16.0 \\
Central & Diamant & 20.0 \\
\hline Southern & Patrones & 5.5 \\
Northeast & Diamant & 15.0 \\
\hline
\end{tabular}

able. ${ }^{14}$ Slightly unfavorable weather conditions such as low temperatures influence symptom expression. In Kenya, certified and obviously healthy (but latently infected) potato seed showed different infections than those planted at lower altitudes. This was due to a latent infection of the tubers grown in an environment less favorable for the pathogen. There are three different pathways through which a potato lot can become infected with brown rot.

Firstly, infections may be caused by irrigation or spraying of potatoes with contaminated surface water, in which brown rot bacteria can occur because of the presence of the host weed (Solanum dulcamara), which is common among many Bangladeshi waterways. Infection through contaminated surface water is called primary infection, because the source of infection is outside the potato production chain. In a disease-free production chain, this is the only way through which an infection can arise. Once brown rot has entered the potato production chain, the pathogen can disperse through the chain by horizontal and vertical transmission mechanisms. Horizontal transmission means infection of a healthy potato lot where the source is another infected lot and can, for instance, be caused by the use of contaminated machinery or equipment. Vertical transmission, also referred to as infection through clonal relationships, indicates transmission of the disease from parent to offspring. This result is an increase in the number of infected lots when an infected, but yet undetected, seed lot is split into minor lots, which are subsequently replanted.

Secondly, the bacterium can spread in soil, in which it survives for several periods of time, and in irrigation (drainage) water. In sub-tropical areas, many weeds have been shown to be alternate hosts. The slow rate of development of the bacterium on the weeds allows them to withstand infection and this provides a bridge for the pathogen between crops. Entry into plants is by way of injured roots, stem wounds or through stomata. Within the plant, the bacteria move in the vascular bundles, a process which is accelerated by higher temperature. Speed of movement is also dependent on the plant part colonized and for instance in tobacco bacteria move quicker in the stalk than in the roots. ${ }^{15}$ This is followed by colonization of tubers produced at altitudes of 1520-2120 m 
the xylem, where the bacteria adhere to the vessel walls or invade the lumen. They adhere by polar attraction to the cell surfaces and subsequently become localized at preferential sites of the mesophyll.

Thirdly, infections of potato tubers may be latent, due to unfavorable weather conditions, partly resistant cultivars or low virulence of certain pathogen strains; tubers with latent infection are the most probable means of introduction into a new area.

\section{Symptoms, detection, and identifi- cation}

On potato plants, the blocking of the vessels by bacteria is the major cause of wilting in potato plants. The organisms cause harms on both clum and tuber. It causes losses in two ways: i) premature wilting and death of the plants leading to total loss of yield; and ii) rotting of the tubers in transit or storage.

The earliest symptom is slight wilting of the leaves at the ends of the branches during the heating of the day which recovery at night; eventually, plants fail to recover and die (Figure 1A), which is soon followed, by total wilting (Figure 1B).

In advanced stage, as the disease develops, a streaky brown discoloration of the stem may be observed on stems up to $2.5 \mathrm{~cm}$ or more above the soil line (Figure 1C) and the leaves turns into a bronze tint. Moreover, epinasty of the petioles may occur and if the base of the stem of the affected plants is cut transversely and squeezed, the bacterial mass is seen to ooze out as a dull white slimy mass on the cut surface which falls spontaneously in the form of threads, when kept in a beaker with water (Figure 2). ${ }^{16}$ Such threads are not formed by other bacterial pathogens of potato. This test is of presumptive diagnostic value in the field. On potato tubers, if infested plants have formed tubers, those will possibly also show symptoms. Two types of symptoms are produced in tubers, vascular rot and pitted lesions. In vascular rot, the vascular tissues looks like a water soaked circle, which subsequently may turn brown (Figure 1D). A crosssection will show a browned vascular bundle ring. As the tuber is pressed, slimy drops will be pressed out of the ring. The lesions on tuber are produced due to infection through lenticels (skin pores). Initially water soaked spots develop, which enlarge forming pitted lesions. The most significant symptom from tuber is the wilting of the plants, even when the soil is moist.

\section{Holistic control approaches}

Potato seed tubers and seeds from other solanaceous plants for planting should have been found free from $R$. solanacearum during the growing season and should come from a

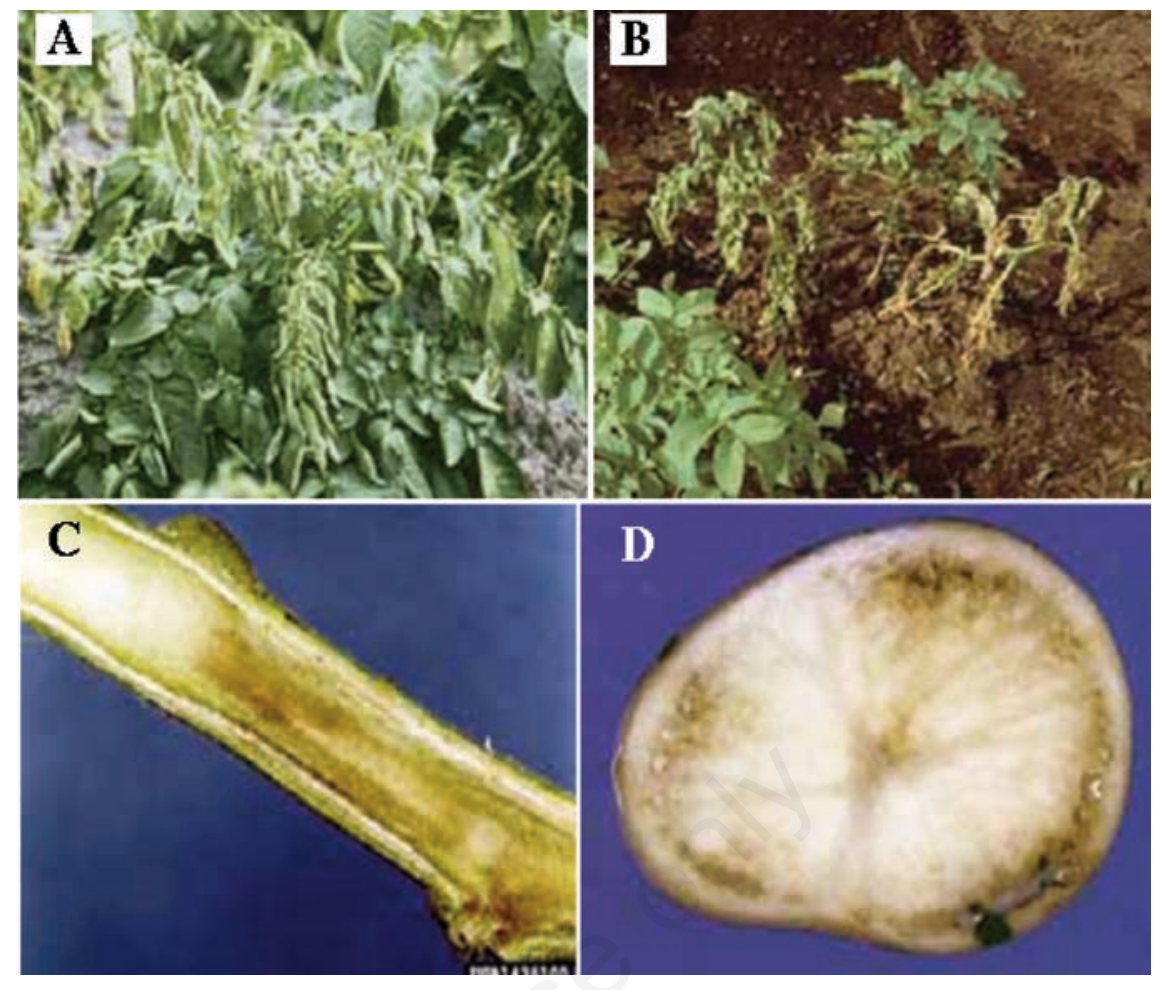

Figure 1. A-D) Chronological symptoms of pathogen on potato plants and tubers.

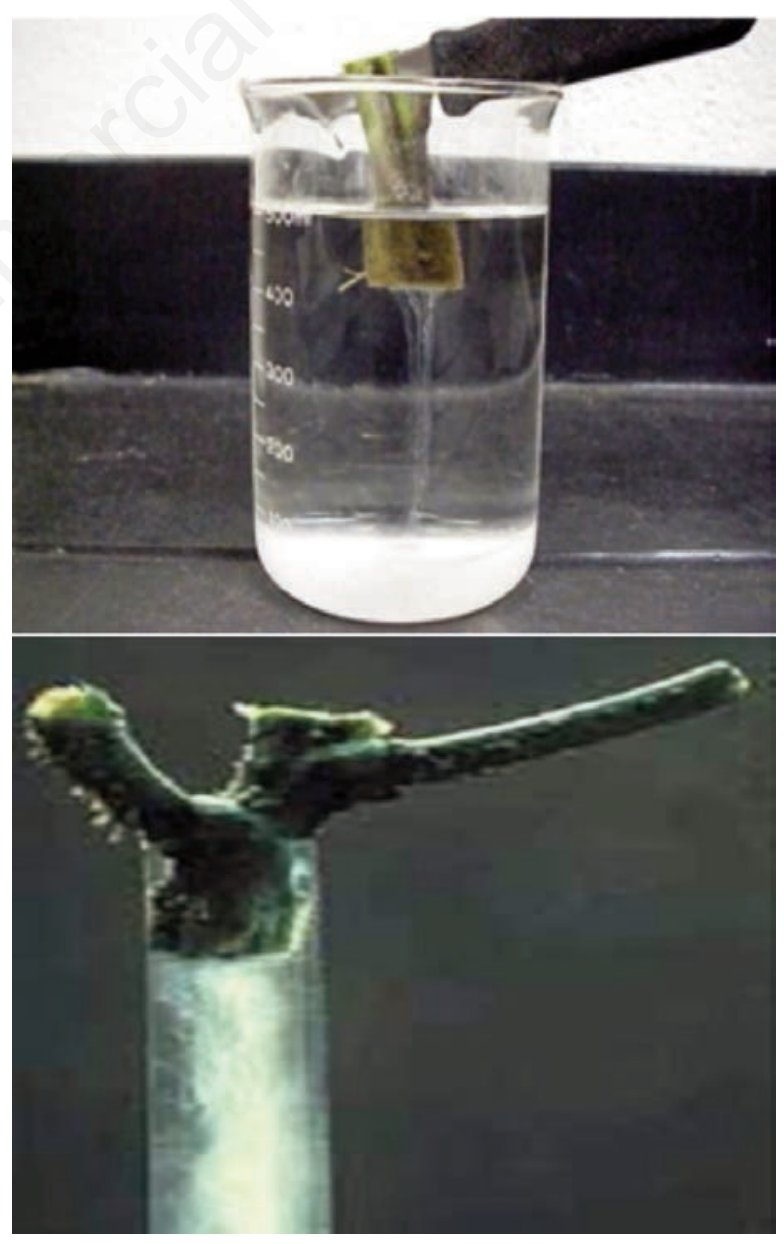

Figure 2. Bacterial ooze detection from infected stem of potato. 
field which was found free from $R$. solanacearum during the last two growing seasons. Visual inspections should be performed routinely upon export and import. Laboratory checks for (latent) infections may be necessary. Plants for planting of potato should be kept in post-entry quarantine to ensure their freedom from dangerous strains of $R$. solanacearum in Bangladesh. As there are no really effective control measures, the golden rule is to prevent the disease and the total control or eradication of Ralstonia solanacearum still remains the dream for most researchers. There are no methods that were practiced $100 \%$ massively by farmers in Bangladesh due to imbalances in knowledge, economic stamina and technology. Some countries are almost close to eradication of $R$. solanacearum like European countries while others are far from even quantifying the incidences countrywide. Eradication of the pathogen is difficult because of the experimental errors, sampling errors, level of efficiency of the eradication method or tool, natural reintroduction of the pathogen, ${ }^{17}$ and technological imbalance which leads to the exporting of some tubers with latent infection.

The infected seed tubers, including apparent healthy seed tubers from diseased crop, are important in spread and carryover of the disease. Hence, disease-free seed tubers obtained from disease-free areas should be used for planting. Splitting of the tubers at the time of the planting should be avoided as splitting spreads the disease even to health tubers. Practicing crop rotation for 2-3 years with crops like maize, finger millet, cereals, garlic, lupin, and onion cabbage can reduce the disease inoculum. ${ }^{18}$ Intercropping of potato with maize or Phaseolus vulgaris reduced inoculum density and disease development in some cases.

Positive results were achieved with the antagonistic bacteria Bacillus polymyxa and Pseudomonas fluorescens which controlled bacterial blight on potato in laboratory experiments in the Philippines. ${ }^{19}$ Biological control measures are becoming more common in integrated pest management (IPM) and integrated disease management (IDM).

Research have been developed in trying to come up with plants that can be grown with potato to reduce bacterial wilt incidences and to come up with positive beneficial microbes to counter soil pathogens, and incorporation of some parts of the plant to inhibit survival of pathogens.

This control measure becomes the last measure when all other avenues of disease control are exploited. Even though there are a few synthetic chemicals, which effectively control bacterial wilt. The use of sodium or calcium chloro-oxide ( $\mathrm{Na}$ or $\mathrm{CaClO}$ ), chlorine dioxide $\left(\mathrm{ClO}_{2}\right)$, anti-biotic, organic acids like lactic acids and acetic acids had shown some effectiveness in controlling bacterial pathogens. Fumigating the soil with chloropicrin was also reported to be effective in Okinawa prefecture, ${ }^{20}$ however, it is rarely used due to its panging smell and its harmful effects to people and environment. Chemicals are rather used to control blight (e.g. Dithane M45, Daconil etc.) and some pests like aphids. The disease may also be controlled by application of fertilizers to change soil $\mathrm{pH}$. In the USA, the pathogen was eradicated by lowering the soil $\mathrm{pH}$ to 4-5 in summer and raising it to $\mathrm{pH} 6$ in the autumn. The disease is serious on sandy, loam, clay and peat soils, but it is never found in marl soils. Application of stable bleaching powder (12-15 kg/ha) mixed with fertilizer in furrows while planting reduces the wilt incidence by $80 \%$.

\section{Conclusions}

The production and export strategies are interlinked with each other for betterment of farmers in Bangladesh. Brown rot pathogen affected the potatoes since 1993 till now. But, last year the Russian Federation banned the potato import from Bangladesh due to brown rot pathogen. So, by applying the proper pre and post sanitary measures during export and import in all ports the intensity and severity could be maintained sincerely. Appropriate holistic approaches of cultural, biological and chemical measures could maintain and reduce brown rot pathogen from Bangladesh as a whole. As a result, the threats can be reduced and socio-economic condition of Bangladeshi farmers will be improved in near future.

On the basis of following topics the research should be conducted in future to verify the intensity and severity of this pathogen in Bangladesh as a wholeto: i) identify all of the species, races, and biovars of the causal organism of bacterial wilt of potato from every potato grown leading areas in Bangladesh; ii) integrate the control of potato bacterial wilt; iii) screening of new potato varieties/lines against resistant of potato bacterial wilt; iv) survey the bacterial wilt of potato in farmers' fields and seed production units; v) take proper quarantine measures during exports and import; vi) conduct a research on another interlinked pathogen with brown rot.

\section{References}

1. FAOSTAT. Statistical Database 2013; Food and Agricultural Organization of United States.

2. Bangladesh Bureau of Statistic (BBS).
Agricultural Statistics Yearbook 20122013.

3. Zehr EI. Studies of the distribution and economic importance of Pseudomonas solanacearum in certain crops in the Philippines. Philippine Agriculturist 1996;53:218-23.

4. French ER, Sequeira L. Bacterial wilt or moko of plantain in Peru. Fito Patologia 1968;3:27-38.

5. Volcani Z, Palti J. Pseudomonas solanacearum in Israel. PI Dis Report 1960;44:448-9.

6. Zachos DG. The brown rot of potatoes in Greece. In. Benaki BP, ed. Annales de l'Institut Phytopathologique Benaki: Kiphissia, Athènes; 1957. pp 115-7.

7. Chen WY. Influence of the root-knot nematode on wilt resistance of flue-cured tobacco infested by Pseudomonas solanacearum. Bull Tobacco Res Inst Taiwan 1984;21:44-8.

8. Sitaramaiah K, Sinha SK. Interaction between Meloidogyne javanica and Pseudomonas solanacearum on brinjal. Indian J nematol 1984;14:1-5.

9. Bill H, Edward RF. Integrated management of bacterial wilt. Proceedings of the Int workshop held, 1993 0ct 11-1, New Delhi, India.

10. Elphinstone JG. The current bacterial wilt situation: a global overview. In: Allen C, Prior P, Hayward A C, eds, Bacterial wilt disease and the Ralstonia solanacearum species complex: The American Phytopathol Soc, St. Paul, USA, 2005. pp 928.

11. Saddler GS. Burkholderia solanacearum. IMI Descriptions of pathogenic fungi and bacteria no. 1220. CAB International 1994; Wallingford, UK.

12. Buddenhagen IW, Sequeira L, Kelman A. Designation of races of pseudomonas solanacearum. Phytopathol 1962;52:726.

13. Hayward AC. Pseudomonas solanacearum: bacterial wilt and moko disease. In: Fahy PC, Persley GJ, eds. Plant bacterial diseases. Sydney, Australia: Acad Press; 1983. pp 129-135.

14. Nesmith WC, Jenkins SF. Influence of antagonists and controlled matric potential on the survival of Pseudomonas solanacearum in four North Carolina soils. Phytopathol 1985;75:1182-7.

15. Ono K, Hara H, Akazawa J. Ecological studies on the bacterial wilt, caused by Pseudomonas solanacearum. V. The movement of the pathogen in tobacco plants. Bull. Okayama Tobacco Exp Stn 1984;43: 41-6.

16. Champoiseau PG, Jones JB, Allen C. Ralstonia solanacearum race 3 biovar 2 causes tropical losses and temperate anxieties. PI Health Prog 2009;10:1-10. 
17. Janse JD, Wenneker M. Possibilities of avoidance and control of bacterial plant diseases when using pathogen tested (certified) or treated planting material. Pl Pathol 2002;51:523-36.

18. CIP. Major Potato Diseases, Insects, and Nematodes. Lima, Peru, CIP, 1996.
19. Aspiras RB, de la Cruz AR. Potential biological control of bacterial wilt in tomato and potato with bacillus polymyxa FU6 and pseudomonas fluorescens. In: Persley GJ, ed. Bacterial wilt disease in Asia and the South Pacific. Proceedings of the Int Workshop held at PCARRD, Los Banos,
Philippines, Oct 8-10, ACIAR Proc 1985;13: 89-92.

20. Ooshiro A, Takaesu K, Natsume M, et al. Identification and use of a wild plant with antimicrobial activity against Ralstonia solanacearum, the cause of bacterial wilt of potato. Weed Biol Manag 2004;4:187-94. 